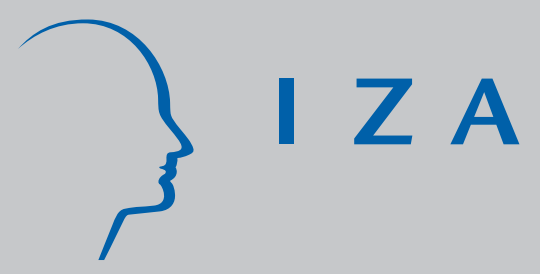

IZA DP No. 974

Are People Inequality Averse, and Do They Prefer Redistribution by the State? A Revised Version

J ohannes Schwarze

Marco Härpfer

December 2003 


\title{
Are People Inequality Averse, and Do They Prefer Redistribution by the State? A Revised Version
}

\author{
Johannes Schwarze \\ University of Bamberg, DIW Berlin \\ and IZA Bonn \\ Marco Härpfer \\ University of Bamberg

\section{Discussion Paper No. 974 December 2003}

\author{
IZA \\ P.O. Box 7240 \\ D-53072 Bonn \\ Germany \\ Tel.: +49-228-3894-0 \\ Fax: +49-228-3894-210 \\ Email: iza@iza.org
}

This Discussion Paper is issued within the framework of IZA's research area Welfare State and Labor Market. Any opinions expressed here are those of the author(s) and not those of the institute. Research disseminated by IZA may include views on policy, but the institute itself takes no institutional policy positions.

The Institute for the Study of Labor (IZA) in Bonn is a local and virtual international research center and a place of communication between science, politics and business. IZA is an independent, nonprofit limited liability company (Gesellschaft mit beschränkter Haftung) supported by Deutsche Post World Net. The center is associated with the University of Bonn and offers a stimulating research environment through its research networks, research support, and visitors and doctoral programs. IZA engages in (i) original and internationally competitive research in all fields of labor economics, (ii) development of policy concepts, and (iii) dissemination of research results and concepts to the interested public. The current research program deals with (1) mobility and flexibility of labor, (2) internationalization of labor markets, (3) welfare state and labor market, (4) labor markets in transition countries, (5) the future of labor, (6) evaluation of labor market policies and projects and (7) general labor economics.

IZA Discussion Papers often represent preliminary work and are circulated to encourage discussion. Citation of such a paper should account for its provisional character. A revised version may be available on the IZA website (www.iza.org) or directly from the author. 
IZA Discussion Paper No. 974

December 2003

\section{ABSTRACT}

\section{Are People Inequality Averse, and Do They Prefer Redistribution by the State? A Revised Version*}

We link life-satisfaction data to inequality of the pre- and post-government income distribution at the regional level, to estimate the degree of inequality aversion. Three different inequality measures are used. In addition, we investigate whether a reduction in inequality by the state increases individual well-being. We find only weak evidence that Germans are inequality averse. Inequality reduction by the state does not increase wellbeing. On the contrary, inequality reduction imposes an excess burden on middle-income earners. The paper uses data from the German Socio-economic Panel Study (GSOEP) from 1985 to 1998.

JEL Classification: $\quad$ C23, D31, D63, I31

Keywords: inequality aversion, redistribution, life satisfaction, panel data

Corresponding author:

Johannes Schwarze

University of Bamberg

Feldkirchenstrasse 21

96045 Bamberg

Germany

Tel.: +499518632600

Email: johannes.schwarze@sowi.uni-bamberg.de

\footnotetext{
* This paper is a revised version of IZA Discussion Paper No. 430. We thank Markus Pannenberg and Gert Wagner, in Berlin, Heinz-Dieter Wenzel, in Bamberg, and seminar participants at the DIW Berlin and at Frankfurt University for helpful comments. The revised version of the paper has benefited greatly from comments by Andrew E. Clark.
} 


\section{Introduction}

Most industrialized countries redistribute income from rich to poor. Revenue from progressive income taxation and payroll taxation is distributed to individuals through both monetary and nonmonetary transfer payments. Redistribution policy reduces income inequality, from the perspective of the pre-government income distribution, and results in a more equal post-government income distribution. Table 1 shows the extent of income redistribution by the state for selected OECD countries. Inequality is measured by the Gini coefficient. It can be seen that Northern European countries reduce income inequality by about 50 percent, and Germany does so by 35 percent. Even in the United States, the reduction of pre-government inequality through redistribution is about 25 percent.

Table 1: Income redistribution by the state in selected OECD countries

\begin{tabular}{lccc}
\hline Country and year & $\begin{array}{c}\text { Gini Before Taxes } \\
\text { and Transfers (1) }\end{array}$ & $\begin{array}{c}\text { Gini After Taxes and } \\
\text { Transfers (2) }\end{array}$ & $\begin{array}{c}\text { \% Changes } \\
(2) /(1)-1\end{array}$ \\
\hline Germany, 1994 & 43.6 & 28.2 & -35.3 \\
Denmark, 1994 & 42.0 & 21.7 & -48.3 \\
Sweden, 1994 & 48.8 & 23.4 & -52.1 \\
Italy, 1993 & 51.0 & 34.5 & -32.4 \\
United States, 1995 & 45.5 & 34.4 & -24.5 \\
\hline
\end{tabular}

Note: All Gini coefficients are computed for household incomes using an equivalence scale elasticity of 0.5. Source: OECD, 1997.

Economic theory advances a wide range of hypotheses to explain and legitimize redistribution by the state. For convenience, we summarize the main hypotheses with reference to three arguments as follows. The first is an efficiency argument. Individual preferences might be better satisfied by institutions such as the state if private transactions are affected by market failure. The second argument is related to self-interest. Redistribution policy is driven by elections, group pressure, rent seeking, and so on. A popular model is that of the median voter. Another is the theory of Rawls (1971). The basic hypothesis of the third argument is that people are intrinsically inequality averse, which means that inequality aversion enters individual utility functions. A possible justification for this is that individuals are altruistic or prefer a more equal income distribution, which then becomes something of a 'public good' (see Thurow, 1971 for a discussion). While the underlying motivation is of less interest to economists, whether such preferences provide 
additional legitimization (beyond efficiency concerns) for political redistribution is of interest.

In this paper, we focus on the third argument. We link survey data from the German Socioeconomic Panel Study (GSOEP) on individual income satisfaction to the extent of regional income inequality. In contrast to other recent studies, however, we do not use postgovernment income inequality to test whether people are inequality averse, because we argue that post-government income inequality is not an ideal indicator. Instead, we decompose post-government income inequality into its constituent parts, namely pregovernment income inequality and the extent of redistribution by the state. Thus, we are able to analyze whether people are inequality averse and also whether they support redistribution by the state.

The GSOEP provides information over a period of 14 years for West Germany on individual life satisfaction as well as information on several individual economic and sociodemographic determinants of life satisfaction. In addition, the use of panel data allows one to control for unobserved individual heterogeneity. For each year, pregovernment and post-government income inequality is computed for 75 regional areas within West Germany. In what follows, Section 2 contains some theoretical considerations and preliminary empirical findings. Section 3 describes our approach to linking satisfaction data and income inequality, describes the data, and explains the estimation methods. The estimation results are presented in Section 4. Finally, Section 5 concludes the paper.

\section{Theoretical considerations and Previous Empirical Findings}

Because our study focuses on inequality aversion, we briefly discuss the relationships between inequality aversion and some of the other arguments for explaining redistribution already mentioned.

The basic idea behind the inequality aversion argument is that people are inequality averse, irrespective of their economic status. Supposing that people are inequality averse in this sense, one could ask whether everyone would support redistribution by the state. Theoretically, altruistic preferences could be satisfied by private voluntary donations. However, the 'market for charity' can fail, and in this case, there would be no voluntary changes in the income distribution (see, for example, Hochman and Rodgers, 1969). This 
might constitute a quasi-efficiency argument for compulsory redistribution by the government. The government tries to fulfill individual preferences for redistribution by using a tax-financed transfer policy. If preferences over income distributions are homogeneous, perhaps because of a national consensus, a tax and transfer policy may represent individual preferences well. However, it might be difficult for the government to fulfill preferences for a less unequal income distribution if individual preferences are extremely heterogeneous. In either case, if government policy reflects individual preferences for a less unequal income distribution and preferences are reasonably homogeneous, most individuals would support redistribution by the government, because it would increase their welfare irrespective of their economic position. On the other hand, if no support is forthcoming, it might be fallacious to conclude that people are not inequality averse.

The efficiency argument does not rely on inequality aversion to legitimize redistribution policies. If people are risk averse and are willing to pay to reduce the risk associated with their ex ante income distribution, they might support redistribution because this is necessary for protection through the social security system (see, for example, Barr, 1998; Sinn, 1995).

Given the self-interest argument, people might be expected to support government policies designed to achieve greater redistribution if they expect to gain from these programs. Thus, redistribution is driven by self-interest, in which case, one would expect support for redistribution to depend not only on individual income and on social status, but also on income mobility. When income mobility tends to zero-that is, when income uncertainty is low-the median voter demands a high degree of redistribution. Greater mobility reduces redistribution if expected income shocks move the median voter up the income distribution-that is, if income shocks have a positive mean. If income shocks have a negative mean, the demand for redistribution increases. When income shocks have a zero mean and people are risk averse, greater income mobility increases the demand for redistribution. The latter result might be interpreted as a variant of Rawls' 'maximin principle' (see Alesina et al. 2001b; Benabou and Ok 2001). Summing up, the self-interest argument does not rely on inequality aversion in the form of altruism. In this context, risk aversion seems to be more important. Furthermore, it might be difficult to distinguish between risk aversion and inequality aversion in empirical studies. This is because 
aversion to (ex post) income inequality might be interpreted as a consequence of individual risk aversion to the ex ante expected individual income distribution.

While the circumstances under which individuals prefer redistribution by the state are discussed extensively in theory, empirical work on this issue is rare. However, recent papers have used 'stated preferences' from population surveys to analyze preferences for political redistribution.

Corneo (2001) and Corneo and Grüner (2000 and 2001) have used data from the International Social Survey Programme (ISSP) on 12 countries, including Eastern European countries, Germany, and the United States. They have analyzed responses to the question of whether it is the government's responsibility to reduce income differentials between people earning high incomes and those on low incomes. Three competing hypotheses that may lead individuals to support redistribution policies were tested. The 'homo oeconomicus', or self-interest, effect measures whether individuals support redistribution because they expect to gain from these policy programs. The idea behind the 'public values effect' is that there is a social welfare function that expresses individuals' preferences for a less unequal income distribution. Thirdly, the authors test a 'social rivalry effect', which suggests that individual preferences for redistribution depend on the effect of redistribution on relative living standards. Corneo and Grüner (2001) find empirical support for all three effects. However, only the public values effect can be interpreted indirectly as evidence of inequality aversion. In this context, inequality aversion implies that individuals intrinsically prefer a less unequal income distribution irrespective of their own position in the income distribution.

Fong (2001) analyzes data from the 1998 Gallup Poll Social Audit Survey. The dependent variable used in this study is a summative scale of five questions on whether governments should reduce inequality. While Fong (2001) finds little evidence for the hypothesis that redistribution is driven by self-interest, social preferences seem to be important.

The studies by Corneo and Grüner (2001) and Fong (2001) do not explicitly address the question of whether individuals are inequality averse. This is done by Alesina et al. (2001a), who analyze whether individuals are inequality averse by relating the inequality observed in society to individual differences in satisfaction with life. Life satisfaction may 
serve as an indicator of individual well-being. If people are inequality averse, one would expect income inequality to have a negative effect on life satisfaction. Like Corneo and Grüner (2001), Alesina et al. (2001a) also used cross-national survey data and found that preferences for a more equal income distribution are stronger in Western Europe than they are in the United States. The authors argue that preferences for a more equal income distribution may not only be due to 'taste', but may also reflect other factors in society, such as the level of social mobility. However, the study by Alesina et al. (2001a) provides no evidence that Europeans are inequality averse irrespective of their own income. While the authors found the poor to be deeply affected by inequality, they found nothing comparable among the rich. They did not test whether inequality aversion generates support for redistribution policies.

Using longitudinal data from the British Household Panel Study (BHPS), Clark (2003), even found that post-government income inequality has a positive effect on life satisfaction.

\section{Life Satisfaction and Income Inequality: Data and Estimation Methods}

Our empirical approach is based on linking perceptions of regional income inequality and the reduction of inequality by the government to individual data on life satisfaction. We measure inequality at the regional level. It is reasonable to assume that individuals are affected more by inequality within their own region than by nationwide inequality (see Hagerty, 2000). Regional inequality is observed by people as least as well as is nationwide inequality. In addition, this approach has the advantage of increasing the number of observations on inequality in a national survey. If life satisfaction measures something akin to individual welfare, income inequality is expected to have a negative effect on life satisfaction if people are inequality averse. A reduction in inequality through redistribution is expected to have a positive effect on life satisfaction if people support redistribution policy.

In this section, the approach to linking satisfaction data and income inequality is discussed first. Then, the data from the GSOEP is described and the estimation methods are explained. 


\subsection{Linking Life Satisfaction and Income Inequality}

As in some other surveys, a question on life satisfaction is asked in the GSOEP (Table 2).

Table 2: Question on Life Satisfaction in the GSOEP.

Question: How satisfied are you with your life, all things considered?

Please answer according to the following scale: ' 0 ' means completely dissatisfied, ' 10 ' means completely satisfied.

Source: http://www.diw.de/deutsch/sop/service/fragen/index.html

Economists have traditionally been skeptical about life-satisfaction data because this type of data measures stated rather than revealed preferences. However, satisfaction data (and happiness data) have been used more frequently by economists in recent years. Satisfaction data have been used to analyze, among other issues, labor market issues (see, for example, Clark and Oswald, 1994; Winkelmann and Winkelmann, 1998), public-choice related issues (see, for example, Frey and Stutzer, 2000), income, income uncertainty, and wellbeing (see, for example, Schwarze, 1994, 2003). (See Frey and Stutzer, 2000 for an overview.) A recent approach by Van Praag et al. (2003) links satisfaction with different aspects of life to a structural model of life satisfaction. The paper by Alesina et al. (2001a), which links cross-national inequality to life satisfaction, has already been mentioned. An early paper on this topic is by Morawetz et al. (1977), who compared the distributions of life satisfaction among communities with differing degrees of inequality.

Analysis of life satisfaction by economists, and earlier and more recent work by psychologists (for an overview, see Diener et al., 1999; Frey and Stutzer, 2000; Frey and Stutzer, 2001) have shown that life satisfaction is a valid measure of individual well-being. Frey and Stutzer (2000, p. 159) conclude: "Happiness is a 'subjectivist' measure of individual welfare, and is much broader than the way individual utility is normally defined.... While happiness is not derived from actual behavior, it is systematically and closely connected with generally accepted manifestations of well-being." One could argue that life satisfaction not only measures individual utility, but also reflects aspects of social utility. Therefore, satisfaction data could reveal preferences for a less unequal income distribution.

Income inequality can be measured as the inequality of pre-government income ('market' income) or as the inequality of post-government income (disposable income). Post- 
government inequality can be defined as the inequality of the pre-government income distribution after redistribution by the state through taxes and transfer payments. In practice, individuals mainly observe post-government inequality and arguably, this is what they really care about. In our first model, life satisfaction is regressed on post-government income inequality:

$$
S_{i r t}=X_{i r t} \beta_{1}+Y_{i r t} \beta_{2}+\operatorname{IPOST}_{r t} \beta_{3}+\mu_{r}+v_{t}+\alpha_{i}+\varepsilon_{i r t}
$$

Life satisfaction, $S$, of person $i$ in region $r$ at time $t$ can be explained by a vector of individual sociodemographic characteristics, $X$, and by information on individual income and the relative income position, represented by the vector $Y$. In addition, the model includes a measure of post-government income inequality (IPOST). The coefficient vectors to be estimated are denoted by $\beta ; \mu_{r}$ is a fixed effect for the region in which the individual lives, $v_{t}$ is a fixed time effect, $\alpha_{i}$ is an unobserved individual effect, and $\varepsilon_{i r t}$ is an error term.

If post-government income inequality reduces the life satisfaction of individuals irrespective of their income, it can be argued that individuals are inequality averse in the sense of the third argument (for example, altruism) discussed above. ${ }^{1}$ However, if no negative influence of the post-government income inequality were found, this would not indicate a lack of inequality aversion. Furthermore, recent studies should not have drawn this inference (see, for example, Alesina et al. 2001a). The reason is that it is possible that society's preference for a more equal income distribution is accounted for by the state's redistribution policy. In this case, post-government income inequality would not have any effect on life satisfaction, even if individuals are inequality averse.

This empirical problem can be solved by decomposing post-government income inequality into its constituent parts-namely, pre-government income inequality and the extent of redistribution by the state. We assume that individual welfare is affected by both components, but in different ways. This is especially true if people are averse to the inequality generated by inequalities in market opportunities. ${ }^{2}$ Thus, the estimated model

\footnotetext{
${ }^{1}$ Note, however, that this is a necessary but not a sufficient condition for inequality aversion. If ex post income inequality serves as an indicator of the individual ex ante income distribution, increasing income inequality might be interpreted as increasing individual income risk and thus might decrease the well-being of risk-averse individuals.

${ }^{2}$ In this case, the state can only redistribute the market outcomes but not the inequality itself. Thus, individuals may be affected negatively by pre-government income inequality although redistribution takes place.
} 
includes a measure of pre-government income inequality (IPRE) and a measure of income redistribution by the state (STATE) as follows:

$$
S_{i r t}=X_{i r t}^{\prime} \beta_{1}+Y_{i r t}^{\prime} \beta_{2}+I P R E_{r t} \beta_{3}+\operatorname{STATE}_{r t} \beta_{4}+\mu_{r}+v_{t}+\alpha_{i}+\varepsilon_{i r t}
$$

The variable STATE measures the effect of government tax and transfer policies on the pregovernment income inequality of the regions as follows: ${ }^{3}$

$$
\text { STATE }_{r t}=\left|\frac{I P O S T_{r t}}{I P R E_{r t}}-1\right|
$$

If people are inequality averse, IPRE is expected to have a negative impact on life satisfaction. STATE is expected to have a positive sign if people support the reduction of inequality by the state.

Note, however, that STATE depends on IPRE. Thus, for an alternative measure, we compute the partial effect of IPRE on life satisfaction:

(4) $\frac{\delta S}{\delta I P R E}=\beta_{3}+\beta_{4}\left(-\frac{I P O S T}{I P R E^{2}}\right)$

If the effect of inequality on life satisfaction is negative, further discussion is required. Is the effect independent of the individual's income position? It would not be surprising if people in a low-income position are averse to society's income distribution. Finding that only low-income households are inequality averse would not provide strong evidence of overall inequality aversion. (Recall the self-interest argument above.) Such a conclusion would require evidence that the life satisfaction of middle- and high-income earners is negatively affected by income inequality. To examine whether inequality affects satisfaction irrespective of an individual's own income position, we extend our model by including interaction effects between the individual's income position and regional inequality. The individual income position is measured by terciles of the overall pregovernment income distribution.

\subsection{Data and Measures of Income Inequality}

The GSOEP is a representative longitudinal micro-data base that includes a wide range of socioeconomic information on randomly selected households in Germany. The first set of data was collected from approximately 6,000 families in the western states in 1984. After German reunification in 1990, the GSOEP was extended by about 2,200 families from the

\footnotetext{
${ }^{3}$ STATE was also computed as the difference between Pre- and Post-Government Inequality. However, the results differ little from the percentage changes.
} 
eastern states. ${ }^{4}$ For estimation, we used data from an unbalanced panel from 1985 to 1998. We concentrate on the West German population of working age (between 20 and 60 years of age). Respondents who answered in at least two years are included.

The following sociodemographic characteristics, which have been discussed in the literature as potential determinants of life satisfaction, are included in all regressions: age, age squared, gender, nationality, years of education, marital status, whether widowed, whether divorced, household size, number of children, place of abode, whether employed full time, whether employed part time, and whether unemployed. Another potentially important variable - the health status of the individual—could not be included because there is no health measure in the GSOEP for the whole period.

The individual's income position is included in the regression in the form of the log of equivalent household disposable income. ${ }^{5} \mathrm{We}$ also include the relative income position of the individual in the form of the income quintile to which the individual belongs. A dummy variable indicating whether the major source of household disposable income is a public transfer program is included. This might affect life satisfaction through stigmatization. In addition, we use the $\log$ of pre-government household income as a predictor of life satisfaction. Including income as well as the individual's income position in a panel data model may well control for the income mobility effects discussed in Section 2. Panel data estimation methods make use of the within-individual variation of the covariates and thus of changing income positions within the period under study.

We compute inequality by using the regional income distribution for each respondent from the GSOEP. IPOST $T_{\mathrm{rt}}$ is the inequality of the post-government income distribution in region $r$ at time $t . I P R E_{\mathrm{rt}}$ is the corresponding pre-government inequality. Annual pre-government income is defined as the sum of gross earnings, capital income, and private transfer income across all household members. Post-government income is defined as pre-government income minus income tax and payroll tax payments plus public transfer payments. The regions are the 75 Raumordnungsregionen (ROR) of West Germany. The ROR are specific regional areas based on the administrative structure beneath the state level of West

\footnotetext{
4 The GSOEP data used in this study are available as a 'scientific use' file (see Wagner et al., 1993). For further information, please contact the German Institute for Economic Research (DIW), Berlin: http://www.diw.de/soep/.

5 As Davis (1984) has shown, income change, as a predictor of life satisfaction, is more important than income itself. However, income change is implicitly considered in these methods.
} 
Germany (see Bundesamt für Bauwesen und Raumordnung, 1999). ${ }^{6}$ Thus, the number of observations on inequality is $r$ multiplied by $t$ (that is, 75 multiplied by 14).

Because both pre- and post-government incomes are calculated in the GSOEP at the household level, we apply an equivalence scale so households of different sizes are comparable. The scale chosen for our analysis approximates the commonly used (revised) OECD scale. This scale assigns a weight of unity to the first adult, 0.5 to all other adults, and 0.3 to children. The results are not sensitive to the equivalence scale chosen.

It is widely accepted that social welfare and its distribution are normative concepts. Because each inequality measure represents a particular type of a normative social welfare function (see Blackorby and Donaldson, 1978), we use different measures of inequality. The measures should satisfy the requirements of the Dalton-Pigou principle of transfers, and the properties of population replication and mean independence (see Cowell, 1995). Because pre-government income can be zero, the measures should also be computable when income is zero. Therefore, we have chosen three measures: the Gini Coefficient, the measure proposed by Theil, and the Atkinson Measure. The Theil measure is a generalized entropy measure and thus satisfies the strong principle of transfers, as well as the requirements listed above. The Atkinson Measure is based on an explicitly defined social welfare function, in which relative inequality aversion is represented by the constant parameter $\varepsilon$ (see Atkinson, 1970). The larger the parameter the greater the degree of society's inequality aversion. In the literature on income inequality, $\varepsilon$ is often chosen to be unity. We follow this convention. Descriptive statistics for all inequality and redistribution measures are reported in the appendix (see Appendix, Table A1).

\subsection{Estimation Methods}

Because responses to the life satisfaction question are from an ordinal scale, an appropriate estimator for our models is the ordered probit. However, the satisfaction scale may be used differently by different respondents (which is analogous to the ordinal-cardinal debate in utility theory). This may generate correlations between the unobserved individual characteristics included in $\alpha_{i}$ and some of the explanatory variables (such as household income) and thereby lead to inconsistent estimation of the parameters. However, the availability of panel data enables the model to be estimated as a fixed-effects or random-

\footnotetext{
${ }^{6}$ The regional data can be obtained from the GSOEP group at the DIW Berlin (http://www.diw.de/soep/).
} 
effects model, and thereby deals with some of these problems. In particular, if $\alpha_{i}$ is modeled as a fixed effect, it is possible to control for inter-individual differences in the scaling and anchoring of responses, intrinsic differences in scaling, and unobserved variables. If this heterogeneity is constant over time, the estimators are unbiased. Unfortunately, there is no readily available formulation of the fixed-effects ordered probit estimator (see, for example, Greene, 2000). An alternative is the random-effects ordered probit model. However, the assumption that unobserved heterogeneity is independent of the explanatory variables is untenable. The random-effects specification was also rejected by a Hausman test. Thus, we present three models. First, we estimated an ordered probit. We calculated robust standard errors using the Huber/White estimator of the variance and grouped the data by individuals to relax the assumption of independence over time. Second, we estimated an ordinary least squares pooled regression, also with robust standard errors as described above. The signs and significance of the estimated parameters are substantively the same in both models. ${ }^{7}$ Third, we estimated a fixed-effects model to control for unobserved heterogeneity. ${ }^{8}$

It could be argued that the repeated measurement of life satisfaction using panel data has an effect on respondents' answers. We controlled for this possibility by including a variable that measures the number of times a respondent has answered the question on life satisfaction during the estimation period.

\section{Estimation Results}

The empirical results are shown in the following tables. Only the estimated coefficients for inequality and inequality reduction are presented. The tables in the appendix include all the estimated parameters. Most of the estimates are consistent with those in the empirical literature on life satisfaction. As expected, life satisfaction increases with pre-government income and the net income of the household. The position in the income distribution has no effect on life satisfaction, except for those on the lowest incomes. Compared with other individuals, those at the bottom of the income distribution are less satisfied with their lives.

\footnotetext{
See also Pannenberg and Schwarze (2000).

${ }^{7}$ Hamermesh (2001) and DiTella et al. (2001) also used ordinary least squares (OLS) to analyze satisfaction scales. They concluded that there are no substantial differences between OLS and ordered probit estimates. ${ }^{8}$ As pre-government inequality and inequality reduction by the state are measured at the regional level, both independent variables are more highly aggregated than is the dependent variable (life satisfaction). This may bias the estimated standard errors of the independent variables (see Moulton, 1990). However, the panel data estimation methods used in this paper control for fixed regional effects and thus alleviate the problem.
} 
We now consider the effect of inequality on life satisfaction and well-being. First, we discuss the model in which satisfaction is regressed on post-government income inequality. The parameter estimates reported in Table 3 indicate that post-government income inequality has a significantly negative effect on life satisfaction, but only when it is measured by the Gini coefficient or by the Theil index. There are no substantial differences between the estimates from the different estimation methods. The Atkinson measure of post-government inequality is only significant at the 10 percent level in the ordered probit model.

Table 3: Life satisfaction and income inequality—estimates from panel data (selected variables)

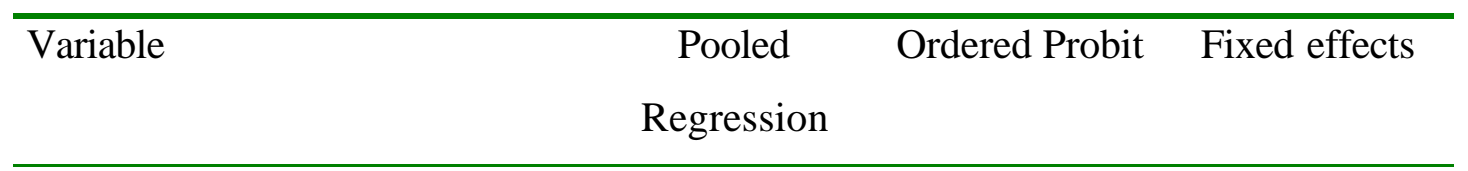

\section{Post-Government Inequality}

(IPOST) measured by:

\section{Gini Coefficient}

$$
-0.4813 * *
$$

$-0.4210 * * *$

(0.1574)

$-0.2546$

(0.1793)

Theil Measure

Atkinson (1) Measure

$$
-0.3554 * * *
$$
$-0.3624 * *$

$$
-0.2619 * *
$$

(0.0930)

$$
-0.1744 *
$$

\footnotetext{
Robust standard errors are in parentheses. The variance-covariance matrix for the ordered probit and pooled regressions is clustered by individuals.

Other variables: Age, age squared, sex, nationality, years of education, married, widowed, divorced, size of household, children, real estate, full-time employed, part-time employed, unemployed, disposable income (log), disposable income position (quintiles), pre-government income (log), public transfers, income taxes (percent), payroll taxes (percent), fixed time effects (14), fixed regional effects (73).

${ }^{*}$ Statistically significant at the $10 \%$ level, ${ }^{* *}$ at the $5 \%$ level, ${ }^{* * *}$ at the $1 \%$ level. Number of cases: $94528 / 11838$.

Source: GSOEP, 1985-1998.
}

Table 4 reports the coefficients of the interaction terms between regional income inequality and the individual's income tercile position. ${ }^{9}$ Only the fixed-effects regression estimates

\footnotetext{
${ }^{9}$ An alternative procedure would be to include the main effects (IPRE, IPOST, STATE) and two interaction effects. (The results are not shown here.) In this case, only the main effects are significant; the interaction effects are not.
} 
are presented here. ${ }^{10}$ Note that individuals' income positions are already controlled for by the inclusion of dummy variables.

Table 4: Life satisfaction and income inequality by income terciles-fixed-effects estimates from panel data (selected variables)

\begin{tabular}{|c|c|c|c|}
\hline \multirow[t]{2}{*}{ Variable } & \multicolumn{3}{|c|}{ Inequality measured by: } \\
\hline & Gini & Theil & Atkinson (1) \\
\hline & Coefficient & Measure & Measure \\
\hline \multicolumn{4}{|c|}{ Post-Government Inequality (IPOST) by } \\
\hline \multicolumn{4}{|c|}{ Terciles: } \\
\hline \multirow[t]{2}{*}{ IPOST $^{*}$ PreT $_{1}$} & $-0.5801 * * *$ & $-0.6349 * * *$ & $-0.5930 * * *$ \\
\hline & $(0.1691)$ & $(0.1473)$ & $(0.1649)$ \\
\hline \multirow[t]{2}{*}{ IPOST $^{*}$ PreT $_{2}$} & -0.2572 & -0.0499 & -0.0370 \\
\hline & $(0.1661)$ & $(0.1376)$ & $(0.1546)$ \\
\hline \multirow[t]{2}{*}{ IPOST $^{*}$ PreT $_{3}$} & -0.2510 & -0.0976 & -0.0274 \\
\hline & $(0.1686)$ & $(0.1483)$ & $(0.1632)$ \\
\hline
\end{tabular}

Robust standard errors are in parentheses. The variance-covariance matrix for the ordered probit and pooled regressions is clustered by individuals.

Other variables: Age, age squared, sex, nationality, years of education, married, widowed, divorced, size of household, children, real estate, full-time employed, part-time employed, unemployed, disposable income ( $\log$ ), disposable income position (quintiles), pre-government income (log), public transfers, income taxes (percent), payroll taxes (percent), fixed time effects (14), fixed regional effects (73).

* Statistically significant at the $10 \%$ level, ${ }^{* *}$ at the $5 \%$ level, ${ }^{* * *}$ at the $1 \%$ level.

Number of cases: $94528 / 11838$.

Source: GSOEP, 1985-1998.

Only persons in the first income tercile are negatively affected by post-government income inequality; there is no significant effect for middle- and high-income earners. The estimates are robust to the income inequality measure used. These results confirm the finding of Alesina et al. (2001a) that while poor people in European countries are affected by income inequality, the rich are not. However, as already mentioned, we cannot unequivocally conclude from these results that individuals are not averse to inequality. Our results simply indicate that low-income people are affected negatively by post-government income inequality, and this is probably because individuals with low pre-government incomes would like more redistribution.

\footnotetext{
${ }^{10}$ Using the Hausman test to test the fixed-effects model against the random-effects model indicates evidence of correlation between the individual effects and the regressors, which supports the fixed-effects specification.
} 
Thus, before discussing these results further, we present estimates in which postgovernment income inequality has been decomposed into its constituent parts-pregovernment income inequality (IPRE) and redistribution by the state (STATE). The parameter estimates reported in Table 5 indicate that pre-government income inequality has a significantly negative effect on life satisfaction. This result holds whatever inequality measure is used and whichever estimation method is used. The negative effect of inequality is clearly not significantly reduced by the state's redistribution policy. On the contrary, some of the estimated coefficients are negative although their effects are only statistically significant at the 10 percent level in the fixed-effects regression.

As stated above, STATE depends on IPRE. Thus, we calculate as an alternative measure the partial effect of IPRE on life satisfaction, the coefficients of which are included in Table 5. The partial effects are evaluated at the sample means of IPRE and STATE. There is no negative effect of pre-government income inequality when the Gini Coefficient is used to measure inequality. When the Theil and Atkinson measures are used, the negative effect of inequality on life satisfaction remains statistically significant. This result suggests inequality aversion. 
Table 5: Life satisfaction, income inequality, and redistribution-estimates from panel data (selected variables)

\begin{tabular}{|c|c|c|c|}
\hline Variable & $\begin{array}{c}\text { Pooled } \\
\text { Regression }\end{array}$ & Ordered Probit & Fixed effects \\
\hline \multicolumn{4}{|c|}{$\begin{array}{l}\text { Pre-Government Inequality } \\
\text { (IPRE) measured by: }\end{array}$} \\
\hline Gini Coefficient & $\begin{array}{c}-0.5003 * * * \\
(0.1815)\end{array}$ & $\begin{array}{c}-0.3497 * * * \\
(0.1063)\end{array}$ & $\begin{array}{c}-0.4977 * * * \\
(0.1277)\end{array}$ \\
\hline Theil Measure & $\begin{array}{c}-0.2907 * * * \\
(0.0966)\end{array}$ & $\begin{array}{c}-0.2067 * * * \\
(0.0567)\end{array}$ & $\begin{array}{c}-0.2357 * * * \\
(0.0715)\end{array}$ \\
\hline Atkinson (1) Measure & $\begin{array}{c}-0.1966 * * \\
(0.0812)\end{array}$ & $\begin{array}{c}-0.1343 * * * \\
(0.0482)\end{array}$ & $\begin{array}{c}-0.1484 * * * \\
(0.0576)\end{array}$ \\
\hline \multicolumn{4}{|c|}{ Percent Redistribution (STATE) } \\
\hline Gini Coefficient & $\begin{array}{l}-0.0814 \\
(0.1369)\end{array}$ & $\begin{array}{l}-0.0176 \\
(0.0814)\end{array}$ & $\begin{array}{l}-0.1854 * \\
(0.1025)\end{array}$ \\
\hline Theil Measure & $\begin{array}{l}-0.0053 \\
(0.0712)\end{array}$ & $\begin{array}{c}0.0070 \\
(0.0426)\end{array}$ & $\begin{array}{l}-0.0209 \\
(0.0566)\end{array}$ \\
\hline Atkinson (1) Measure & $\begin{array}{l}-0.0060 \\
(0.1024)\end{array}$ & $\begin{array}{c}0.0047 \\
(0.0602)\end{array}$ & $\begin{array}{c}0.0224 \\
(0.0838)\end{array}$ \\
\hline \multicolumn{4}{|c|}{ Partial Effect of IPRE: } \\
\hline Gini Coefficient & & & -0.2048 \\
\hline Theil Measure & & & $-0.2036 *$ \\
\hline Atkinson (1) Measure & & & $-0.1581 * *$ \\
\hline
\end{tabular}

Robust standard errors are in parentheses. The variance-covariance matrix for the ordered probit and pooled regressions is clustered by individuals.

Other variables: Age, age squared, sex, nationality, years of education, married, widowed, divorced, size of household, children, real estate, full-time employed, part-time employed, unemployed, disposable income $(\log )$, disposable income position (quintiles), pre-government income (log), public transfers, income taxes (percent), payroll taxes (percent), fixed time effects (14), fixed regional effects (73).

${ }^{*}$ Statistically significant at the $10 \%$ level, ${ }^{* *}$ at the $5 \%$ level, ${ }^{* * *}$ at the $1 \%$ level.

Number of cases: $94528 / 11838$.

Source: GSOEP, 1985-1998.

Table 6 reports the results of interacting pre-government income inequality and the percentage redistribution by the state with individual income terciles. These estimates depend significantly on the inequality measure used. When measured by the Gini Index, pre-government inequality significantly lowers life satisfaction for all income terciles. 
Thus, regional pre-government income inequality evidently reduces life satisfaction, irrespective of the individual's own income position. The life satisfaction of the highest earners is negatively affected by income inequality, as is the life satisfaction of people who are in the middle or at the bottom of the income distribution.

However, redistribution by the state does not have a positive effect on life satisfaction. Indeed, for individuals in the middle of the pre-government income distribution, redistribution has a significantly negative effect on life satisfaction. The 'middle class' in German society are most affected by income tax and payroll tax, and therefore, primarily responsible for financing most of the social burden. No significantly negative effect of income redistribution on life satisfaction was found for individuals at the top of the income distribution.

The partial effects of pre-government income inequality (also in Table 6) tell a different story. No significantly negative effect of income inequality on life satisfaction is apparent in any income tercile. Indeed, for the middle tercile, the effect is positive, but not statistically significant. Thus, the partial effects do not provide evidence of inequality aversion.

Whereas the results implied by the Theil measure are comparable to those implied by the Gini measure, they differ from those implied by the Aktinson measure. 
Table 6: Life satisfaction, income inequality, and redistribution by income terciles-fixedeffects estimates from panel data (selected variables)

\begin{tabular}{lccc}
\hline Variable & \multicolumn{3}{c}{ Inequality measured by: } \\
\hline & Gini & Theil & Atkinson (1) \\
& Coefficient & Measure & Measure \\
\hline
\end{tabular}

Pre-Government Inequality (IPRE) by

Terciles:

$\begin{array}{lccc}\text { IPRE }^{*} \mathrm{PreT}_{1} & -0.6583 * * * & -0.3531 * * * & -0.2368 * * * \\ & (0.1552) & (0.1011) & (0.0827) \\ \text { IPRE }^{*} \mathrm{PreT}_{2} & -0.3769 * * * & -0.1391 & -0.1007 \\ & (0.1473) & (0.0965) & (0.0755) \\ \text { IPRE }^{*} \mathrm{PreT}_{3} & -0.4690 * * * & -0.2178 * * & -0.1218 \\ & (0.1575) & (0.1058) & (0.0809)\end{array}$

Percent Redistribution (STATE) by

Terciles:

$\begin{array}{lccc}\text { STATE }^{*} \text { PreT }_{1} & -0.1613 & -0.0528 & 0.0064 \\ & (0.1446) & (0.0697) & (0.0949) \\ \text { STATE }^{*} \operatorname{PreT}_{2} & -0.2504 * & -0.0294 & 0.0196 \\ & (0.1333) & (0.0659) & (0.0911) \\ \text { STATE }^{*} \operatorname{PreT}_{3} & -0.1337 & 0.0180 & 0.0387 \\ & (0.1463) & (0.0710) & (0.0951)\end{array}$

Partial Effect of IPRE:

$\begin{array}{lccc}\text { PreT }_{1} & -0.4034 & -0.2721 & -0.2396 * * \\ \text { PreT }_{2} & 0.0187 & -0.0940 & -0.1091 \\ \text { PreT }_{3} & -0.2578 & -0.2453 & -0.1384\end{array}$

Robust standard errors are in parentheses. The variance-covariance matrix for the ordered probit and pooled regressions is clustered by individuals.

Other variables: Age, age squared, sex, nationality, years of education, married, widowed, divorced, size of household, children, real estate, full-time employed, part-time employed, unemployed, disposable income (log), disposable income position (quintiles), pre-government income (log), public transfers, income taxes (percent), payroll taxes (percent), fixed time effects (14), fixed regional effects (73).

Statistically significant at the $10 \%$ level, ${ }^{* *}$ at the $5 \%$ level, ${ }^{* * *}$ at the $1 \%$ level. Number of cases: $94528 / 11838$.

Source: GSOEP, 1985-1998.

The estimated effects of redistribution on life satisfaction are positive although they are not statistically significant. However, there is no negative effect of pre-government income inequality for the second and third income terciles. Thus, the results implied by the 
Atkinson measure suggest that the effect of inequality aversion on life satisfaction can be reduced by redistribution by the state. This result applies to persons in the middle and third income terciles. For those in the lower income tercile, the negative effect of pregovernment income inequality remains, even when one considers the partial effect.

\section{Conclusions}

Using panel data covering a 14-year period between 1985 and 1998, we regressed life satisfaction, rated on a scale ranging from 0 to 10 , on regional income inequality and on the percentage reduction in inequality achieved through tax and transfer policy. We measured income inequality by using three different indices.

As have other recent papers on this topic, we began with a model in which life satisfaction is regressed on post-government income inequality. However, we argued that the use of post-government income inequality might be inadequate for testing for inequality aversion. Hence, we decomposed post-government income inequality into its constituent parts-pregovernment income inequality and the extent of redistribution by the state.

The results do not clearly indicate whether German people are negatively affected by income inequality. On the one hand, pre-government income inequality affects life satisfaction irrespective of individual income positions, which suggests that people might be averse to inequality. On the other hand, given that the extent of redistribution depends on pre-government income inequality, the partial effect of pre-government income inequality on life satisfaction constitutes only weak evidence for inequality aversion.

However, assuming some inequality aversion, redistribution through government tax and transfer policy evidently cannot reduce welfare losses that are due to income inequality. We found no significantly positive effect on life satisfaction of the percentage reduction in inequality. Indeed, one of our measures suggested that individuals in the middle of the income distribution are affected negatively by redistribution. The estimated reduction in life satisfaction that is due to redistribution might be interpreted as a form of 'excess burden'. 


\section{References}

Alesina, A., R. Di Tella and R. MacCulloch: 2001a, Inequality and Happiness: Are Europeans and Americans Different?, NBER Working Paper 8198 (National Bureau of Economic Research, Cambridge).

Alesina, A., E. Glaeser and B. Sacerdote: 2001b, Why Doesn't the US have a EuropeanStyle Welfare System?, NBER Working Paper 8524 (National Bureau of Economic Research, Cambridge).

Barr, N.: 1998, The Economics of the Welfare State, 3rd edition (Oxford University Press, Oxford).

Benabou, R. and E. A. Ok: 2001, 'Social Mobility and the Demand for Redistribution: The POUM Hypothesis', Quarterly Journal of Economics 116, pp. 447-487.

Blackorby, C. and D. Donaldson: 1978, 'Measures of Relative Equality and Their Meaning in Terms of Social Welfare', Journal of Economic Theory 18, pp. 59-80.

Buhmann, B., L. Rainwater, G. Schmaus and T. J. Smeeding: 1988, 'Equivalence Scales, Well-Being, Inequality, and Poverty: Sensitivity Estimates Across Ten Countries using the Luxembourg Income Study (LIS) Database', Review of Income and Wealth 34, pp. 115-142.

Bundesamt für Bauwesen und Raumordnung: 1999, Aktuelle Daten zur Entwicklung der Städte, Kreise und Gemeinden, Ausgabe 1999 (Bundesamt für Bauwesen und Raumordnung, Berichte Band 3, Selbstverlag, Bonn).

Clark, A. E. and A. J. Oswald: 1994, 'Unhappiness and Unemployment', Economic Journal 104, pp. 648-659.

Clark, A. E.: 2003, Inequality Aversion and Income Mobility: A Direct Test, Working Paper 2003-11 (DELTA, Paris).

Corneo, C.: 2001, Inequality and the State: Comparing U.S. and German Preferences, Working Paper 398 (Center for Economic Studies and Ifo Institute for Economic Research, Munich).

Corneo, C. and H. P. Grüner: 2000, 'Social Limits to Redistribution', American Economic Review 90, pp. 1491-1507.

Corneo, C. and H. P. Grüner: 2001, 'Individual Preferences for Political Redistribution', Journal of Public Economics (forthcoming).

Cowell, F. A.: 1995, Measuring Inequality, Second Edition, Prentice Hall, London. 
Davis, J. A.: 1984, New Money, An Old Man/Lady and 'Two's Company'. Subjective Welfare in the NORC General Social Surveys, 1972-1982, in: Social Indicators Research 15, S. 319-350.

Diener, E., E. Suh, R. Lucas and H. Smith: 1999, 'Subjective Well-Being: Three Decades of Progress', Psychological Bulletin 125, pp. 276-303.

Di Tella, R., R. J. MacCulloch and A. J. Oswald: 2001, 'Preferences over Inflation and Unemployment: Evidence from Surveys of Happiness', American Economic Review 91, pp. 335-341.

Fong, C.: 2001, 'Social Preferences, Self-Interest, and the Demand for Redistribution', Journal of Public Economics 82, pp. 225-246.

Frey, B. S. and A. Stutzer: 2000, 'Maximizing Happiness?', German Economic Review 1, pp. 145-167.

Frey, B. S. and A. Stutzer: 2001, What can Economists Learn from Happiness Research?, Working Paper 503 (Center for Economic Studies and Ifo Institute for Economic Research, Munich).

Greene, W. H.: 2000, Econometric Analysis, Fourth Edition, Prentice-Hall International, London.

Hagerty, M. R.: 2000, ‘Social Comparisons of Income in One's Community. Evidence From National Surveys of Income and Happiness', Journal of Personality and Social Psychology 78, pp. 764-771.

Hamermesh, D. S.: 2001, 'The Changing Distribution of Job Satisfaction', Journal of Human Resources 36, pp. 1-30.

Hochman, H. M. and J. D. Rodgers: 1969, 'Pareto Optimal Redistribution', American Economic Review 59, pp. 542-557.

Morawetz, D. et al.: 1977, 'Income Distribution and Self-Rated Happiness: Some Empirical Evidence', Economic Journal 87, pp. 511-522.

Moulton, B.: 1990, 'An Illustration of a Pitfall in Estimating the Effects of Aggregate Variables on Micro Units', Review of Economics and Statistics 72, pp. 334-338.

Pannenberg, M. and J. Schwarze: 2000, 'Wage Dynamics and Unemployment in Germany: Evidence from Regional Panel Data', Labour 14, pp. 645-655.

van Praag, B. M. S., P. Frijters and A. Ferrer-i-Carbonel: 2003, 'The Anatomy of Subjective Well-Being', Journal of Economic Behavior and Organization 51, pp. $29-49$.

Rawls, J.: 1971, A Theory of Justice, Harvard University Press, Cambridge, MA. 
Schwarze, J.: 1994, Subjective Measures of Economic Well-Being and the Influence of Income Uncertainty, Discussion Paper 94 (German Institute for Economic Research, Berlin).

Schwarze, J.: 2003, 'Using Panel Data on Income Satisfaction to Estimate the Equivalence Scale Elasticity', Review of Income and Wealth 49, pp. 359-372.

Sinn, H.-W.: 1995, 'A Theory of the Welfare State', Scandinavian Journal of Economics 97, pp. 495-526.

Thurow, L. C.: 1971, ‘The Income Distribution as a Pure Public Good', Quarterly Journal of Economics 85, pp. 327.

Wagner, G. G., R. V. Burkhauser and F. Behringer: 1993, 'The English Language Public Use File of the German Socio-Economic Panel', Journal of Human Resources 28, pp. 429-433.

Winkelmann, L. and R. Winkelmann: 1998, 'Why are the Unemployed so Unhappy? Evidence from Panel Data', Economica 65, pp. 1-15. 


\section{Appendix}

Table A1: Descriptive statistics for the three inequality measures

\begin{tabular}{lcccc}
\hline & Mean & Std. Dev. & Min & Max \\
\hline Measured by Gini: & & & & \\
IPRE & 0.4041 & 0.0747 & 0.1611 & 0.7267 \\
IPOST & 0.2576 & 0.0541 & 0.1152 & 0.5261 \\
STATE & 0.3583 & 0.0909 & 0.0405 & 0.6799 \\
Measured by Theil: & & & & \\
IPRE & 0.2862 & 0.1190 & 0.0550 & 1.0071 \\
IPOST & 0.1220 & 0.0639 & 0.0239 & 0.6141 \\
STATE & 0.5620 & 0.1474 & 0.4481 & 0.8848 \\
Measured by Atkinson (1): & & & & \\
IPRE & 0.5265 & 0.1672 & 0.0716 & 0.9700 \\
IPOST & 0.1239 & 0.0569 & 0.0249 & 0.4023 \\
STATE & 0.7549 & 0.0955 & 0.1709 & 0.9351 \\
\hline
\end{tabular}

Observations: $\mathrm{r}=75$ regions, $\mathrm{t}=14$ waves.

Source: GSOEP, 1985-1998.

Table A2: Life satisfaction, inequality aversion, and political redistribution-estimates from panel data, 1985 to 1998: Gini

\begin{tabular}{lccc}
\hline Variable & Ordered Probit & $\begin{array}{c}\text { Pooled } \\
\text { Regression }\end{array}$ & $\begin{array}{c}\text { Fixed-effects } \\
\text { regression }\end{array}$ \\
\hline Age & $-0.0537 * * *$ & $-0.0905 * * *$ & $-0.0712 * * *$ \\
Age squared & $(0.0046)$ & $(0.0077)$ & $(0.0064)$ \\
Female & $0.0006 * * *$ & $0.0010 * * *$ & $0.0003 * * *$ \\
& $(0.0001)$ & $(0.0001)$ & $(0.0001)$ \\
Foreign guest worker & $0.0564 * * *$ & $0.0916 * * *$ & $($ dropped $)$ \\
Years of education & $(0.0158)$ & $(0.0269)$ & \\
& $0.0536 * * *$ & $0.0731 * *$ & $($ dropped $)$ \\
Married & $(0.0188)$ & $(0.0318)$ & \\
Divorced & $0.0096 * * *$ & $0.0203 * * *$ & -0.0028 \\
Widow/Widower & $(0.0033)$ & $(0.0055)$ & $(0.0097)$ \\
& $0.1815 * * *$ & $0.3098 * * *$ & $0.2728 * * *$ \\
Number of household members & $(0.0192)$ & $(0.0326)$ & $(0.0250)$ \\
& -0.0231 & -0.0508 & $0.2300 * * *$ \\
Number of Children & $(0.0340)$ & $(0.0609)$ & $(0.0414)$ \\
& 0.0287 & 0.0366 & $-0.2334 * * *$ \\
& $(0.0540)$ & $(0.0938)$ & $(0.0792)$ \\
& $-0.0632 * * *$ & $-0.1051 * * *$ & $-0.0806 * * *$ \\
& $(0.0063)$ & $(0.0108)$ & $(0.0079)$ \\
& $0.0730 * * *$ & $0.1321 * * *$ & $0.0507 * * *$ \\
\hline
\end{tabular}




\begin{tabular}{|c|c|c|c|}
\hline & $(0.0162)$ & $(0.0272)$ & $(0.0189)$ \\
\hline Own house & $\begin{array}{c}0.0909 * * * \\
(0.0154)\end{array}$ & $\begin{array}{c}0.1493 * * * \\
(0.0257)\end{array}$ & $\begin{array}{c}0.0039 \\
(0.0216)\end{array}$ \\
\hline Full-time employed & $\begin{array}{c}0.0632 * * * \\
(0.0160)\end{array}$ & $\begin{array}{c}0.1302 * * * \\
(0.0271)\end{array}$ & $\begin{array}{c}0.1573 * * * \\
(0.0194)\end{array}$ \\
\hline Part-time employed & $\begin{array}{l}-0.0185 \\
(0.0215)\end{array}$ & $\begin{array}{l}-0.0015 \\
(0.0357)\end{array}$ & $\begin{array}{l}-0.0053 \\
(0.0252)\end{array}$ \\
\hline Self-employed & $\begin{array}{l}-0.0350 \\
(0.0226)\end{array}$ & $\begin{array}{c}-0.0724 * \\
(0.0378)\end{array}$ & $\begin{array}{l}-0.0206 \\
(0.0284)\end{array}$ \\
\hline Unemployed & $\begin{array}{c}-0.3691 * * * \\
(0.0229)\end{array}$ & $\begin{array}{c}-0.7061 * * * \\
(0.0429)\end{array}$ & $\begin{array}{c}-0.5268 * * * \\
(0.0263)\end{array}$ \\
\hline Household income (log) & $\begin{array}{c}0.2335 * * * \\
(0.0256)\end{array}$ & $\begin{array}{c}0.4266 * * * \\
(0.0457)\end{array}$ & $\begin{array}{c}0.3188 * * * \\
(0.0311)\end{array}$ \\
\hline Pre-government household income (log) & $\begin{array}{c}0.0322 * * * \\
(0.0056)\end{array}$ & $\begin{array}{c}0.0653 * * * \\
(0.0106)\end{array}$ & $\begin{array}{c}0.0391 * * * \\
(0.0066)\end{array}$ \\
\hline Lowest income quintile & $\begin{array}{c}-0.0736 * * \\
(0.0365)\end{array}$ & $\begin{array}{c}-0.1078 * \\
(0.0636)\end{array}$ & $\begin{array}{l}-0.0515 \\
(0.0440)\end{array}$ \\
\hline Second income quintile & $\begin{array}{l}-0.0246 \\
(0.0268)\end{array}$ & $\begin{array}{l}-0.0141 \\
(0.0469)\end{array}$ & $\begin{array}{l}-0.0034 \\
(0.0322)\end{array}$ \\
\hline Third income quintile & $\begin{array}{l}-0.0128 \\
(0.0211)\end{array}$ & $\begin{array}{l}-0.0040 \\
(0.0364)\end{array}$ & $\begin{array}{c}0.0188 \\
(0.0256)\end{array}$ \\
\hline Fourth income quintile & $\begin{array}{c}0.0036 \\
(0.0161)\end{array}$ & $\begin{array}{c}0.0204 \\
(0.0272)\end{array}$ & $\begin{array}{c}0.0417 * * \\
(0.0203)\end{array}$ \\
\hline Household receives social assistance & $\begin{array}{c}-0.1192 * * * \\
(0.0351)\end{array}$ & $\begin{array}{c}-0.1941 * * * \\
(0.0667)\end{array}$ & $\begin{array}{l}-0.0163 \\
(0.0424)\end{array}$ \\
\hline Post-Government Inequality (IPOST) & $\begin{array}{c}-0.3554 * * * \\
(0.1301)\end{array}$ & $\begin{array}{c}-0.4813 * * \\
(0.2202)\end{array}$ & $\begin{array}{c}-0.3624 * * \\
(0.1633)\end{array}$ \\
\hline Number of questionnaires completed & $\begin{array}{c}0.0038 * * \\
(0.0019)\end{array}$ & $\begin{array}{c}0.0089 * * * \\
(0.0031)\end{array}$ & (dropped) \\
\hline
\end{tabular}

Other variables: Fixed time effects (14), fixed regional effects (73).

${ }^{*}$ Statistically significant at the $10 \%$ level. ${ }^{* *}$ at the $5 \%$ level. ${ }^{* * *}$ at the $1 \%$ level.

Number of cases: 94528/11838.

Source: GSOEP, 1985-1998. 


\section{IZA Discussion Papers}

\begin{tabular}{|c|c|c|c|c|}
\hline No. & Author(s) & Title & Area & Date \\
\hline 959 & $\begin{array}{l}\text { T. Bauer } \\
\text { H. Bonin } \\
\text { U. Sunde }\end{array}$ & $\begin{array}{l}\text { Real and Nominal Wage Rigidities and the Rate } \\
\text { of Inflation: Evidence from West German Micro } \\
\text { Data }\end{array}$ & 1 & $12 / 03$ \\
\hline 960 & $\begin{array}{l}\text { A. Constant } \\
\text { K. F. Zimmermann }\end{array}$ & $\begin{array}{l}\text { Circular Movements and Time Away from the } \\
\text { Host Country }\end{array}$ & 1 & $12 / 03$ \\
\hline 961 & $\begin{array}{l}\text { C. N. Teulings } \\
\text { C. G. de Vries }\end{array}$ & $\begin{array}{l}\text { Generational Accounting, Solidarity and Pension } \\
\text { Losses }\end{array}$ & 3 & $12 / 03$ \\
\hline 962 & $\begin{array}{l}\text { L. Goerke } \\
\text { M. Pannenberg }\end{array}$ & $\begin{array}{l}\text { Norm-Based Trade Union Membership: } \\
\text { Evidence for Germany }\end{array}$ & 3 & $12 / 03$ \\
\hline 963 & $\begin{array}{l}\text { L. Diaz-Serrano } \\
\text { J. Hartog } \\
\text { H. S. Nielsen }\end{array}$ & $\begin{array}{l}\text { Compensating Wage Differentials for } \\
\text { Schooling Risk in Denmark }\end{array}$ & 5 & $12 / 03$ \\
\hline 964 & $\begin{array}{l}\text { R. Schettkat } \\
\text { L. Yocarini }\end{array}$ & $\begin{array}{l}\text { The Shift to Services: } \\
\text { A Review of the Literature }\end{array}$ & 5 & $12 / 03$ \\
\hline 965 & $\begin{array}{l}\text { M. Merz } \\
\text { E. Yashiv }\end{array}$ & Labor and the Market Value of the Firm & 1 & $12 / 03$ \\
\hline 966 & T. Palokangas & $\begin{array}{l}\text { Optimal Taxation with Capital Accumulation } \\
\text { and Wage Bargaining }\end{array}$ & 3 & $12 / 03$ \\
\hline 967 & $\begin{array}{l}\text { M. Lechner } \\
\text { R. Vazquez-Alvarez }\end{array}$ & $\begin{array}{l}\text { The Effect of Disability on Labour Market } \\
\text { Outcomes in Germany: Evidence from Matching }\end{array}$ & 6 & $12 / 03$ \\
\hline 968 & $\begin{array}{l}\text { M. Blázquez } \\
\text { M. Jansen }\end{array}$ & $\begin{array}{l}\text { Efficiency in a Matching Model with } \\
\text { Heterogeneous Agents: Too Many } \\
\text { Good or Bad Jobs? }\end{array}$ & 1 & $12 / 03$ \\
\hline 969 & $\begin{array}{l}\text { J.-P. Schraepler } \\
\text { G. G. Wagner }\end{array}$ & $\begin{array}{l}\text { Identification, Characteristics and Impact of } \\
\text { Faked Interviews in Surveys }\end{array}$ & 7 & $12 / 03$ \\
\hline 970 & $\begin{array}{l}\text { G. Kertesi } \\
\text { J. Köllõ }\end{array}$ & $\begin{array}{l}\text { Fighting "Low Equilibria" by Doubling the } \\
\text { Minimum Wage? Hungary's Experiment }\end{array}$ & 4 & $12 / 03$ \\
\hline 971 & $\begin{array}{l}\text { J. De Loecker } \\
\text { J. Konings }\end{array}$ & $\begin{array}{l}\text { Creative Destruction and Productivity Growth in } \\
\text { an Emerging Economy: Evidence from } \\
\text { Slovenian Manufacturing }\end{array}$ & 4 & $12 / 03$ \\
\hline 972 & J. Köllõ & $\begin{array}{l}\text { Transition on the Shop Floor - The Restructuring } \\
\text { of a Weaving Mill, Hungary 1988-97 }\end{array}$ & 4 & $12 / 03$ \\
\hline 973 & $\begin{array}{l}\text { C. Belzil } \\
\text { J. Hansen }\end{array}$ & $\begin{array}{l}\text { Structural Estimates of the Intergenerational } \\
\text { Education Correlation }\end{array}$ & 1 & $12 / 03$ \\
\hline 974 & $\begin{array}{l}\text { J. Schwarze } \\
\text { M. Härpfer }\end{array}$ & $\begin{array}{l}\text { Are People Inequality Averse, and Do They } \\
\text { Prefer Redistribution by the State? A Revised } \\
\text { Version }\end{array}$ & 3 & $12 / 03$ \\
\hline
\end{tabular}

An updated list of IZA Discussion Papers is available on the center's homepage www.iza.org. 